\title{
8.4. АСПЕКТЫ ИНФОРМАЦИОННОЙ БЕЗОПАСНОСТИ В СИСТЕМЕ ЭКОНОМИЧЕСКОЙ БЕЗОПАСНОСТИ ХОЗЯЙСТВУЮЩИХ СУБЪЕКТОВ
}

Макарова Н.Н., д.э.н., доцент, профессор кафедры экономической безопасности и информационных технологий АНОО ВО ЦС РФ «Российский университет кооперации», Волгоградский кооперативный институт (филиал);

Шубович А.А., к.Т.н., доцент, консультант отдела технического обеспечения и работы с базами данных избирателей информационного аппарата Избирательной комиссии Волгоградской области;

Чусов И.А., к.э.н., доцент кафедры экономической безопасности и информационных технологий АНОО ВО

ЦС РФ «Российский университет кооперации», Волгоградский кооперативный институт (филиал);

Бестужева Л.И., к.э.н., доцент кафедры экономической безопасности и информационных технологий АНОО ВО ЦС РФ «Российский университет кооперации», Волгоградский кооперативный институт (филиал)

В настоящее время цифровая экономика представляет собой систему экономических отношений, базирующуюся на использовании цифровых информационно-коммуникационных технологий, что требует совершенствования информационного обеспечения управления. В статье рассматривается информационная безопасность как подсистема экономической безопасности хозяйствующего субъекта, включающей его информационное пространство, анализируются базовые понятия информационной безопасности и обосновывается необходимость защиты инсормации, воспроизводимой в рамках корпоративной информационной системы.

\section{Литература}

1. Об информации, информационных технологиях и о защите информации [Электронный ресурс] : федер. закон от 27 июля 2006 г. №149-Ф3 (ред. от 2 дек. 2019 г.). Доступ из справ.-правовой системы «Консультант Плюс».

2. О Стратегии развития информационного общества в РФ на 2017-2030 гг. [Электронный ресурс] : Указ Президента РФ от 9 мая 2017 г. №203. Доступ из справ.-правовой системы «Консультант Плюс».

3. Р 50.1.053-2005. Информационные технологии. Основные термины и определения в области технической защиты информации [Текст] : Рекомендации по стандартизации. - Введ. 2006-01-01. - М. : Изд-во стандартов, 2005. -13 с.

4. Асаул А.Н. Организация предпринимательской деятельности [Текст] : учеб. / А.Н. Асаул. - СПб. : АНО ИПЭВ, 2009. $336 \mathrm{c}$.

5. Баранова Е.К. Информационная безопасность и защита информации [Текст] : учеб. пособие / Е.К. Баранова, А.В. Бабаш. - 3-е изд., перераб. и доп. - М. : РИОР : ИНФРА-М, 2017. - 322 с.

6. Капулин Д.В. и др. Информационная структура предприятия [Текст] : учеб. пособие / Д.В. Капулин, А.С. Кузнецов, Е.Е. Носкова. - Красноярск : Сиб. федер. ун-т, 2014. - 186 с.

7. Левин В.К. Защита информации в информационно-вычислительных системах и сетях [Текст] / В.К. Левин // Программирование. - 1994. - №5. - С. 5-16.

8. Ловцов Д.А. Развитие информационной сфреры общественно-производственной деятельности: достижения, угрозы безопасности и правовое регулирование [Текст] / Д.А. Ловцов // Государство и право в новой информационной реальности : сб. науч. тр. - М. : ИНИОН РАН, 2018. - С. 15-37.

\section{Ключевые слова}

Информационная безопасность; информационная система; информация; информационная инфраструктура; защита.

\author{
Макарова Надежда Николаевна \\ Шубович Александр Анатольевич
}

Чусов Иван Андреевич

Бестужева Лариса Ирековна

\section{РЕЦЕНЗИЯ}

Актуальность темы обусловлена обострением проблем информационной безопасности в условиях цифровизации и интенсивного развития информационных и коммуникационных технологий. Поэтому исследования, направленные на повышение эффективности управления хозяйствующими субъектами на основе фрормирования системы информационной безопасности, способной обеспечить согласованность действий, являются актуальными.

В статье определена роль информационной безопасности в процессе информационного обеспечения управления хозяйствующих субъектов и проанализированы их информационные ресурсы с позиции необходимости обеспечения их защиты.

Практическая значимость состоит в использовании предложенной графф-модели информационной безопасности корпоративной информационной системы в качестве конкретного организационного и экономического инструментария, направленного на совершенствование методов управления хозяйствующим субъектом.

Представленная на рецензию статья соответствует требованиям, предъявляемым к подобным публикациям, и может быть рекомендована к изданию.

Глинская О.С., д.э.н., доцент, заведующая кафедрой экономической безопасности и информационных технологий, Волгоградский кооперативный институт (филиал), АНАОО ВО ЦС РФ «Российский университет кооперации», г. Волгоград

DOI 10.38097/AFA.2020.56.39.028 
